\title{
Comparative economic performance of traditional and modernised fishmeal units in Veraval, Gujarat
}

\author{
V. CHANDRASEKAR, P. JEYANTHI AND NIKITA GOPAL \\ ICAR-Central Institute of Fisheries Technology, Matsyapuri P.O., Willingdon Island, Kochi - 682 029, Kerala, India \\ e-mail:vcsecon@gmail.com
}

\begin{abstract}
Fish meal is an important feed ingredient produced from trash and low value fishes and is widely used in the poultry, aquafeed and agricultural sector. In addition to traditional sun dried product, modern fish meal is produced by modern fish meal plants. This paper presents a comparison of economic performance of fish meal units adopting the traditional and modern methods of fish meal production in Veraval, Gujarat. The study was conducted among 12 fish meal plants operating in Veraval. In the traditional method, the raw material is sourced from and nearby places within the state which is sun dried and then ground to produce fish meal. In modern fish meal units, through a mechanised production line, raw fish is steam-cooked, dried and finally ground to produce fish meal. Quality of the fish meal produced in the modernised units was found to be superior as compared to traditional fish meal. While sun dried fish meal fetches ₹20-30 $\mathrm{kg}^{-1}$, the fish meal produced in modern units is sold at ₹50-70 $\mathrm{kg}^{-1}$. Even though the initial investment and operational cost, which includes raw material, labour and other overheads is more in the modern method, the price realisation is almost double per unit of the product and the quality of the fish meal is also better than the traditionally produced one. The benefit cost ratio and net present value for modern method was also estimated to be higher.
\end{abstract}

Keywords: Break-even point, Modern fish meal, Sensitivity analysis

\section{Introduction}

Fish meal is an important seafood by product that is used by the poultry, aquafeed and agricultural sectors. Trash fish catch is the major source of raw material for the fish meal plants. Apart from this, the waste generated from fish processing factories and dry fish is also used as raw material (Ponnusamy et al., 2012). In aquaculture, fish meal is one of the major inputs for feed production. Quality of fish meal is determined by content of its crude protein. Internationally marketed fish meal has a crude protein content of $65 \%$ and it varies from 57 to $77 \%$ (Sen et al., 2003) based on the raw material used for fish meal production. The international price of the fish meal varies depending on seasonal variation in supply of fish both in terms of quantity and species. Price of fish meal in India is more or less stable throughout the year. In the past two years, it has been observed that the fish meal prices varied from ₹ 80 to 120 per $\mathrm{kg}$. Along with the traditional sun dried product, a recent development has been the production of modern fish meal in modern fish meal plants. In these modern units, through a mechanised production line, raw fish is cooked, dried and finally ground to produce fish meal. But, the quality and price of the modern fish meal is better than the traditional sundried fish meal and has fine texture and uniformity. Because of improved protein content, lesser moisture (7-8\%) and sand silica $(0.5-2 \%)$ it is preferred for export market. Hence, there is increasing demand for setting up modern fish meal plants using machinery like steam boilers, dryer, coolant, grinder cum pulveriser and packing machine.

Unlike other states, in Gujarat, the type of fish meal produced is different and it is made predominantly from the processing waste and the oil content is less, which is also attributed to the non-availability of oilsardine in the Gujarat coast. Hence the fish oil is not produced as a byproduct in these units and therefore, income of each unit is entirely based on the single product i.e fish meal powder. This paper presents a comparison of economic viability of both traditional and modern fish meal units operated in Veraval in Gujarat State.

\section{Materials and methods}

The present study was undertaken in and around Veraval, Gujarat State during the year 2014-15. Totally, 12 fish meal units were selected for the study covering eight traditional and four modernised fishmeal units. A semistructured interview schedule was used for data collection. The data related to operation of fish meal units were collected from both the units.

\section{Methodology for investment decision making criteria}

The investment decisions were made for starting any production unit, using the discounted cash flow (DCF) decision rules. Among the decision rules, the most well-known are the net present value (NPV) criterion, the internal rate of return (IRR) and benefit/cost ratio (BCR) 
equations, which are given below, assuming the cost of capital at $15 \%$ for calculating the discounted cash flows.

Net present value (NPV): NPV is calculated as the difference between the discounted present value of future benefits and the discounted present value of future costs.

$$
\mathrm{NPV}=\mathrm{PV} \text { (Benefits) - PV (Costs) }
$$

Benefit/cost ratio (BCR): Instead of calculating the NPV by subtracting the PV of costs from the PV of benefits, were PV of benefits is devided by the PV of costs.

$$
\mathrm{BCR}=\frac{\mathrm{PV}(\text { Benefit })}{\mathrm{PV}(\text { Costs })}
$$

Internal rate of return (IRR): The discount rate at which the NPV becomes " 0 " is called the Internal Rate of Return (IRR), which is calculated as:

$$
\operatorname{IRR}=\left\{\begin{array}{c}
\text { Lower } \\
\text { discount } \\
\text { rates }
\end{array}\right\}+\left\{\begin{array}{c}
\text { Difference between } \\
\text { the two discount } \\
\text { rates }
\end{array}\right\} \times\left\{\frac{\mathrm{NPV} \text { at the lower discount rate }}{\text { Sum of the absolute values of NPVs }}\right\}
$$

Break-even point: The break-even point for a product is the point where total revenue received equals the total costs associated with the sale of the product. A break-even point is typically calculated to determine if it would be profitable to sell a proposed product, as opposed to attempting to modify an existing product so that it can be made lucrative. For calculating break-even quantity in this study, one product model is considered (Sathiadhas et al., 2009). The total cost of producing a product can be given by:

$$
\mathrm{BEP}=\frac{\mathrm{TC}}{\mathrm{p}-\mathrm{v}}
$$

where, $\mathrm{BEP}=$ Break-even point, $\mathrm{TC}=$ Total fixed cost, $\mathrm{p}=$ Selling price per unit of fish meal production, $\mathrm{v}=$ Variable cost per unit fish meal production

\section{Sensitivity analysis}

The market 'cost and price' situation always tend to fluctuate based on the demand and supply of the particular product. From the investor point of view, it is important to study the economic viability of the fishmeal units so that it is highly useful to formulate future strategies and investment decision under uncertain market situation. Sensitivity analysis was carried out by making a small percentage change in existing situation of cost and return. For that, different combinations of incremental costs and returns combinations were used to estimate the respective economic viability criteria i.e., benefit-cost (B-C) ratio, net present value (NPV) and internal rate of return (IRR), which were worked out at $15 \%$ discount rate.

\section{Results and discussion}

The bycatch (trash fish) mainly from trawlers and waste generated from fish processing plants are the source of raw material for fish meal production in Veraval. Almost $66 \%$ of the fish meal units operating in Veraval were found to follow traditional method of fish meal production and the rest of the units were directly producing fish meal using the improved method without extraction of fish oil. Unlike other states producing fish meal, oilsardine is not used as raw material for fish meal here due to non-availability of the same in Gujarat coast. In addition to catfish, other species like lizard fish, dhoma, barracuda, threadfin bream and ribbon fish are used for preparing fish meal. Suguna Poultry Industries in Tamil Nadu was the major buyer of fish meal from Gujarat.

There are 12 fish meal plants operating in Veraval, out of which four are using the modern method of production. Predominantly, fish meal in Veraval is prepared by sun drying the fishes up to $12-16 \%$ moisture level and then going for direct grinding. In this traditional method, dried fish like lizard fish, dhoma, barracuda, head part of catfish, thread fin bream, ribbon fish, trash fishes and jawala (juvenile shrimp) are procured from Veraval and nearby places within Gujarat like Navibandar, Jafrabad, Rajpara, Vanakbara, Okha, Mangrol, Veraval which is sun dried for 3 to $6 \mathrm{~h}$ based on the moisture content and then ground to produce fish meal. These traditional types of fish meal are of lower quality and mainly purchased by domestic poultry industries (Palod et al.,1996).

The traditional and modernised production line flow charts for fish meal unit in Veraval are given in Fig. 1. On comparing the two, the investment is higher in the modern units for machineries like raw fish cutting machine, boiler, dryer, cooler, grinder cum pulveriser and conveyor. This investment on machinery is required for improvement of the quality of fish meal produced. The major quality parameters taken into consideration for pricing fish meal are the percentage composition of protein, moisture, sand silica and salt content. The quality comparison between the sun dried and modern fish meal in terms of protein, moisture, sand silica and salt percentage are given in Table 1. Modern fish meal is comparatively clean and of better quality than traditionally produced fish meal. The traditional sundried fish meal is mostly purchased by the domestic poultry industry, whereas the modern one is sourced mainly by aquafeed manufacturers for both domestic as well as international markets.

The purchasing price of raw fishes used for modern fish meal plant varies from ₹5 to 10 per $\mathrm{kg}$ (Table 2) which is dependent upon the season and availability of fish. The traditional fish meal units purchase raw material in both dry as well as wet form based on the availability. The price of dry fish varies from ₹15 to 25 per $\mathrm{kg}$ while the price of raw fish varies from ₹4 to 5 per $\mathrm{kg}$. About $90 \%$ of fish comes from Navabandar, Jaffrabad and Rajpara, of which $80 \%$ is contributed by jawala (tiny shrimp) and the rest by lizard fish (Saurida tumbil), dhoma (croaker), barracuda (Sphyraena 

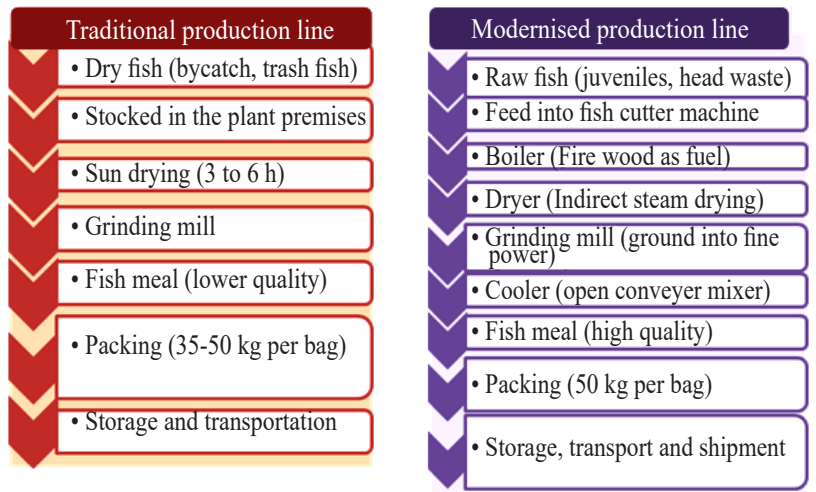

Fig. 1. Traditional and modernised production lines of fish meal units in Veraval

Table 1. Comparison of quality of sun dried and modern fish meal (Personal communication from fish meal producers)

\begin{tabular}{lll}
\hline Particulars & Sun dried fish meal & Modern fish meal \\
\hline Protein (\%) & $40-45$ & $50-55$ \\
Moisture (\%) & $12-16$ & $7-9$ \\
Sand (\%) & $4-8$ & $0.5-2$ \\
Salt (\%) & $3-6$ & $<2$ \\
Usage & Poultry industry & Aqua feed \\
\hline
\end{tabular}

Table 3. Average investment in modern fish meal production unit

\begin{tabular}{ll}
\hline Investment particulars & Amount (₹ lakhs) \\
\hline Cutting machine (50HP) & 4.00 \\
Boiler & 20.00 \\
Dryer & 50.00 \\
Cooler & 4.00 \\
Grinder cum pulveriser (50HP) & 4.00 \\
Packing machine & 0.10 \\
Weighing balance & 0.80 \\
Chimney 24 x 85ft & 1.00 \\
50 HP motor (2 nos.) & 0.80 \\
5 HP motor (7 nos.) & 0.84 \\
Conveyer & 2.00 \\
Total machinery & 85.54 \\
\hline
\end{tabular}

and Tamil Nadu, the modern fish meal units have operational capacity of about $100 \mathrm{t}$ per day (Aswathy et al., 2013). As per the survey in and around Veraval, the fish meal units operate with less than $20 \mathrm{t}$ capacity of raw material in wet form, which is more profitable in both traditional and modern methods. The conversion percentage from raw fish to fish meal is more in traditional method $(22.5 \%)$ as compared to modern fishmeal units $(18 \%)$. This may be due to the

Table 2. General particulars of both sun dried and modern fish meal units in Veraval

\begin{tabular}{lll}
\hline Particulars & Sun dried fish meal & Modern fish meal \\
\hline No of fish meal units & 8 & 4 \\
Fish species used as raw material & Dried juvenile fishes and cutting waste of & Processing waste (catfish, ribbon fish, \\
& jawala, croaker, ribbon fish and crab waste & leatherjacket, threadfin bream) \\
Cost of fish $\left(₹ \mathrm{~kg}^{-1}\right)$ & $4-5$ & $5-10$ \\
Machines & Grinder (50 HP motor) & Cutter, Boiler, Dryer, Cooler, Grinder \\
Price of fish meal $\left(₹ \mathrm{~kg}^{-1}\right)$ & $20-30$ & $50-70$ \\
\hline
\end{tabular}

jello), head of catfish, threadfin bream, ribbon fish and trash fishes. Recovery of fish meal in modern fish meal plant is $15-20 \%$, whereas in traditional fish meal plants, recovery is only $25 \%$.

\section{Investment cost on machinery}

The investment particulars for modern fish meal production unit in Veraval are given in Table 3. The installed capacity is about of 50-100 t per day, but on an average, these are operating at 10-20 t per day for 8 to 9 months based on the availability of fish. The total investment on machinery is about ₹85.5 lakh, out of which, dryer machine itself accounts for $55 \%$ of the cost while the boiler ( $₹ 20$ lakh) and dryer together accounts for $78 \%$ of investment.

Table 4 represents the annual cost and return comparison of both traditional and modern fish meal plants in Veraval with processing capacity of about $20 \mathrm{t}$ per day of raw material in wet form. However, in other states like Karnataka, Kerala poor quality resulting from higher content of sand silica and moisture. The annual return is worked out for 200 days at an average price rate of ₹25 and 58 per $\mathrm{kg}$ of fish meal from traditional and modern fish meal units, respectively. The machinery used in the traditional units is only a single grinding machine, whereas modern units are fully equipped with machinery right from raw material receiving to final product. On comparison, the initial investment on modern fish meal unit is three times higher than the traditional units. The internal rate of return was 44 and $37 \%$ for traditional and modern units indicating that both traditional as well as modern fish meal units are feasible. The benefit-cost ratio and net present value are also acceptable, but the values for traditional units were lower than that of the modern units as more labour is used in traditional fish meal units.

\section{Decision making model for fish meal units}

In the analysis, the average cost of financing to start a fish meal unit was taken as $15 \%$ per annum. Represented 
Table 4. Average annual cost and return comparison of both traditional and modern fish meal plants in Veraval (Processing $20 \mathrm{t}$ fish per day) (₹ lakhs)

\begin{tabular}{|c|c|c|}
\hline \multirow{2}{*}{ Particulars (per annum) } & \multicolumn{2}{|c|}{ Cost and returns (₹ lakhs) } \\
\hline & $\begin{array}{l}\text { Traditional } \\
\text { fish meal unit }\end{array}$ & $\begin{array}{l}\text { Modern } \\
\text { fish meal unit }\end{array}$ \\
\hline \multicolumn{3}{|l|}{ Investment } \\
\hline $\begin{array}{l}\text { Buildings and other } \\
\text { structures }\end{array}$ & 50.00 & 60.00 \\
\hline $\begin{array}{l}\text { Machinery including } \\
\text { boiler }\end{array}$ & 4.00 & 100.00 \\
\hline Fixed cost & 54.00 & 160.00 \\
\hline Depreciation & 1.73 & 4.80 \\
\hline Interest on fixed capital & 5.40 & 16.00 \\
\hline Costs of management & 1.50 & 1.80 \\
\hline Insurance & 0.10 & 1.00 \\
\hline Total fixed cost & 8.73 & 23.60 \\
\hline \multicolumn{3}{|l|}{ Variable costs } \\
\hline Cost of fish & 160.00 & 260.00 \\
\hline Labour & 14.00 & 8.00 \\
\hline Electricity & 2.20 & 12.65 \\
\hline Fire wood & 0.00 & 21.60 \\
\hline Lab testing fees & 0.00 & 0.20 \\
\hline $\begin{array}{l}\text { Interest on working } \\
\text { capital }\end{array}$ & 18.00 & 30.00 \\
\hline Total operational cost & 194.00 & 333.00 \\
\hline Total cost & 203.00 & 356.00 \\
\hline \multicolumn{3}{|l|}{ Returns } \\
\hline $\begin{array}{l}\text { Fishmeal } \\
(\text { ('TFMU } 900 \text { t @ ₹25 kg-1) } \\
\text { (\#MFMU } 720 \text { t@ @ } 58 \text { kg }^{-1} \text { ) }\end{array}$ & 225.00 & 417.60 \\
\hline Fish waste & 2.00 & 0.00 \\
\hline Gross revenue & 227.00 & 417.60 \\
\hline Annual net profit & 24.00 & 61.00 \\
\hline Benefit cost ratio (BCR) & 1.12 & 1.17 \\
\hline Net present value (NPV) & 74.00 & 161.00 \\
\hline Internal rate of return (IRR) & 44.00 & 37.00 \\
\hline
\end{tabular}

"TFMU - Traditional fish meal unit \#MFMU - Modern fish meal unit

graphically (Fig. 2), the area greater than $15 \%$ discount rate will be accepted for finance and less than $15 \%$ discount rate is not suitable for investing for both the projects. Using the IRR decision rule, it would appear that traditional fish meal unit is preferable to modern unit given that the IRR is $44 \%$ for traditional unit, as opposed to $37 \%$ for modern fish meal unit. However, if the NPV decision-rule is used by discounting the future net benefits of each investment at $15 \%$, the NPV is ₹105 lakh for traditional and ₹238 lakh for modern units, which is higher. Based on the NPV decision-rule, naturally modern units are preferred than traditional ones. At the

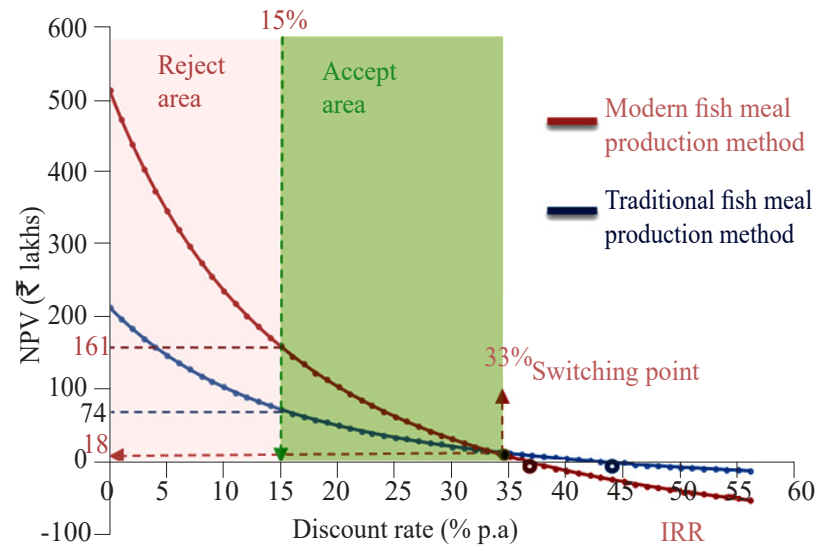

Fig. 2. Decision making graph using NPV of the two different fish meal production methods

switching point, the NPV curves of the two projects cross over at $33 \%$. In other words, at a discount rate of $33 \%$, the NPV of traditional unit is equal to the NPV of modern fish meal unit. At all discount rates below 33\%, the NPV of modern fish meal unit is greater than the NPV of traditional units and at all discount rates above $33 \%$, the NPV of modern unit is less than the NPV of traditional unit.

\section{Break-even point analysis}

The break-even quantity of fish meal produced by both traditional and modern methods was calculated with existing cost and market price situation during the study period (2014-15). The study revealed that the traditional type of fish meal producer present in Veraval has to produce at least $1.26 \mathrm{t}$ of fish meal per day, otherwise annually on an average, it has to operate for 200 days to produce fish meal of $252 \mathrm{t}$ for getting a no profit no loss condition as shown in Fig. 3. The quantity above $252 \mathrm{t}$ will generate profit. Similarly for modern fish meal unit, break-even point is calculated as $1 \mathrm{t}$ per day or 200 t per annum, as indicated in Fig. 4.

Economic viability fish meal unit - using sensitivity analysis

The annual cost and return for traditional fish meal unit operating at $20 \mathrm{t}$ capacity of raw fish is ₹203 and 227 lakh, respectively. Similarly for the modern fish meal unit, annual cost and return were ₹356 and 417 lakhs, respectively. Additional cost and return for both the fish meal units were analysed with change in cost and return of 0,5 and $10 \%$ for both positive and negative combination. The positive symbol indicates the increase of percentage change in cost and benefit and vice-versa.

The sensitivity analysis at different combination of cost and price condition of both traditional and modern fish meal units is presented in Table 5. It shows that the B-C ratio is greater than one for all combinations in modern unit and the occurrence of positive NPV, except wherever 10\% 


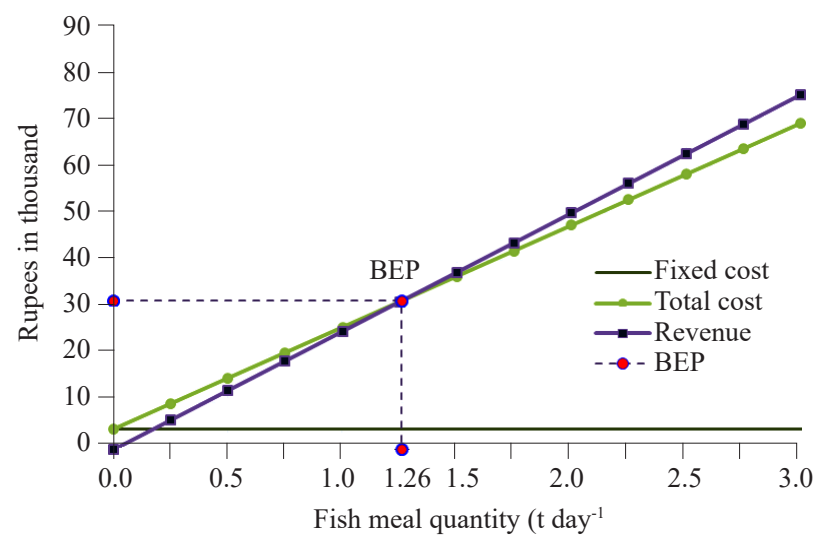

Fig. 3. Break-even quantity of traditional fish meal (t day $\left.{ }^{-1}\right)$

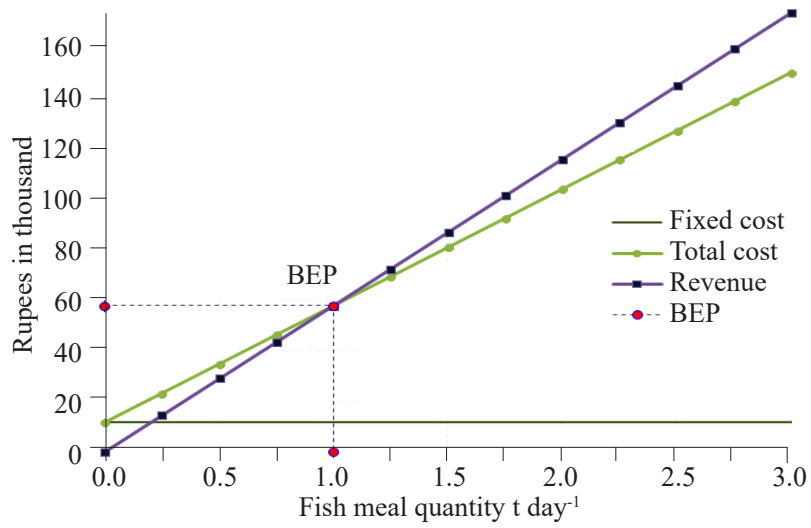

Fig. 4. Break-even quantity of modern fish meal (t day $\left.{ }^{-1}\right)$

Table 5. Economic viability of the traditional and modern fish meal unit and sensitivity analysis

\begin{tabular}{|c|c|c|c|c|c|c|c|}
\hline \multirow{2}{*}{$\%$ Change in cost } & \multirow{2}{*}{$\%$ Change in benefit } & \multicolumn{3}{|c|}{ Traditional unit } & \multicolumn{3}{|c|}{ Modern unit } \\
\hline & & $\mathrm{BCR}$ & NPV & IRR \% & BCR & NPV & IRR \% \\
\hline 0 & 0 & 1.12 & 74 & 44 & 1.17 & 161 & 37 \\
\hline 0 & -5 & 1.06 & 12 & 20 & 1.12 & 55 & 23 \\
\hline-5 & 0 & 1.18 & 125 & 63 & 1.24 & 258 & 49 \\
\hline 0 & +5 & 1.17 & 131 & 65 & 1.23 & 274 & 51 \\
\hline+5 & 0 & 1.06 & 18 & 23 & 1.12 & 71 & 25 \\
\hline+10 & 0 & 1.02 & -35 & -4 & 1.07 & -22 & 12 \\
\hline 0 & +10 & 1.23 & 190 & 86 & 1.29 & 383 & 65 \\
\hline 0 & -10 & 1.01 & -47 & -17 & 1.06 & -54 & 6 \\
\hline-10 & 0 & 1.24 & 178 & 82 & 1.30 & 351 & 61 \\
\hline-5 & +10 & 1.29 & 244 & 105 & 1.36 & 476 & 76 \\
\hline+10 & -5 & 0.97 & -94 & $(-\mathrm{ve})$ & 1.01 & -131 & -13 \\
\hline-10 & +5 & 1.30 & 237 & 103 & 1.37 & 460 & 74 \\
\hline+5 & -10 & 0.96 & -100 & (-ve) & 1.01 & -147 & -22 \\
\hline-5 & -10 & 1.06 & 6 & 18 & 1.11 & 39 & 21 \\
\hline+5 & +10 & 1.17 & 137 & 67 & 1.23 & 290 & 53 \\
\hline
\end{tabular}

incremental costs and $10 \%$ decrease in benefits were showing negative net present value. Similarly, for traditional fish meal unit where B-C ratio, NPV and IRR show negative value at $10 \%$ incremental cost and $10 \%$ reduction in benefit levels. This indicates that both types of fish meal units will not remain economically viable under this scenario, if percentage change in cost goes higher. As a whole, the analysis indicates higher rate of return on capital invested compared to the opportunity cost of capital at 15\% (rate at which banks are generally extending long-term loan) and thereby, confirming the economic viability of both traditional as well as modern units.

Evaluation of the products shows that the quality of the fish meal produced in the modernised units is superior.
While sun dried fish meal fetches ₹20-30 $\mathrm{kg}^{-1}$, the fish meal produced in modern units is sold at ₹55-70 $\mathrm{kg}^{-1}$. Even though the initial investment and operational cost, which includes raw material, labour and other overheads is more in the modern method, the price realisation (NPV) is almost double per $\mathrm{kg}$ and quality of the fish meal is also better than traditional one. The benefit-cost ratio and net present value for modern method were also higher. Based on the sensitivity analysis, $10 \%$ increase in costs or $10 \%$ decrease in benefits showed negative net present value.

\section{References}

Aswathy, N. and Narayanakumar, R. 2013. Economic analysis of fishmeal plants in Uttara Kannada District, Karnataka. Mar. Fish. Infor. Serv. T\&E Ser., 217: 5-7. 
Palod, J. and Baghel, K. P. S. 1996. Influence of fish meal scales on carcass yield, organ weight and processing losses in broiler. Indian J. Anim. Nutr., 13(1): 43 -46.

Ponnusamy, K., Ambasankar, K. and Ponniah, A. G. 2012. Production and marketing of fish meal in India - a study. Indian J. Fish., 59(1): 147-149.
Sathiadhas, R., Najmudeen, T. M. and Prathap, S. 2009. Break-even analysis and profitability of aquaculture practices in India. Asian Fish. Sci., 22: 667-680.

Sen, A., Parmar, H., Badonia, R. and Nair, K. G. R. 2003. A perspective on the fish meal industry in Gujarat. In: Sustainable fisheries development - Focus on Gujarat, p. 168-173. 